Bull. Mater. Sci., Vol. 22, No. 1, February 1999, pp. 17-20. (C) Indian Academy of Sciences.

\title{
High temperature compression testing and determination of warm working temperature for commercial purity aluminium
}

\author{
B K RAO, M S A KHADAR and K SRINIVASAN* \\ Department of Metallurgical and Materials Engineering, KREC, Surathkal, Srinivasnagar 574 157, India
}

MS received 27 January 1998; revised 30 April 1998

\begin{abstract}
CP aluminium was subjected to axysymmetric compression testing at $303,373,473,573$ and $673 \mathrm{~K}$. Strength coefficient and strain hardening exponent were determined from $\log -\log$ plot of true stress and true strain at different temperatures. True stress vs temperature at different strains indicated that dynamic strain ageing (DSA) occurred between 473 and $673 \mathrm{~K}$. Warm working is to be done between $423 \mathrm{~K}$ and $473 \mathrm{~K}$, so that optimum substructure hardening and strain hardening can be achieved during mechanical processing.
\end{abstract}

Keywords. Stress; strain; temperature; warm working; compression testing; billet.

\section{Introduction}

Strain hardening is the only method available for strengthening commercial purity aluminium (Hatch 1984). As working temperature increases strain hardening decreases (Avner 1974). In hot working $\left(T_{\mathrm{w}}>0.6 T_{\mathrm{M}}\right)$ no effective strain hardening occurs due to the processes of dynamic recovery and recrystallization (Dieter and Bacon 1988). Aluminium is more prone to dynamic recovery because it has a high stacking fault energy of $200 \mathrm{~mJ} / \mathrm{m}^{2}$ (Reed Hill and Reza Abbaschian 1994). To obtain maximum strength, cold working $\left(T_{\mathrm{w}}=R T\right)$ can be used but it has its own problems such as higher stresses and requirement of high capacity presses (Van Horn 1967). Warm working is attractive $\left(R T<T_{\mathrm{w}}<0.6 T_{\mathrm{M}}\right)$. It avoids the pitfalls of hot working and cold working and at the same time combines the advantages of both processes (Lange 1985). To determine the exact temperature range for warm working one must know the temperature at which DSA occurs and avoid this range. Flow properties must be known at warm working temperatures to predict the forces required, select presses of sufficient capacity and choose lubrication and suitable tooling. Various aspects of high temperature deformation of aluminium alloys were investigated in the past by several groups (Hammond et al 1977, 1980; Rao et al 1984a, b; Rao and Prasad 1986; Hammond 1987). The variation of $n$ with temperature is discussed for mild steels (Bergstrom and Aronsson 1972). In most of the above works the yield stress variation with temperature was dealt with. In the current work, mean flow stress $\left(\sigma_{\mathrm{fm}}\right)$ is dealt with. If initial strain and final

*Author for correspondence strain are given by $\varepsilon_{\mathrm{i}}$ and $\varepsilon_{\mathrm{f}}$ and $K$ and $n$ are known at a given temperature the mean flow stress will be

$$
\sigma_{\mathrm{fim}}=\left[1 /\left(\varepsilon_{\mathrm{f}}-\varepsilon_{\mathrm{i}}\right)\right]\left[K(\varepsilon)^{n+1} /(n+1)\right]_{\varepsilon_{\mathrm{i}}}^{\varepsilon_{\mathrm{r}}}
$$

This helps in the estimation of forces for warm working more accurately and enables one to choose presses of sufficient capacity, tooling to withstand the expected stresses and lubrication that is adequate to minimize friction and reduce wear.

\section{Experimental}

Commercial purity aluminium rods were annealed at $573 \mathrm{~K}$ for $30 \mathrm{~min}$ and then machined into cylindrical specimens of height $\left(h_{0}\right) 30 \mathrm{~mm}$ and diameter $\left(d_{0}\right) 20 \mathrm{~mm}$ to give an initial $h_{0} / d_{0}$ of 1.5 .

These samples were heated in a furnace at 373,473 , 573 and $673 \mathrm{~K}$ for sufficient time $(2 \mathrm{~h})$, transferred to an UTM of $20 \mathrm{~T}$ capacity, and upset at the high temperature. Graphite in oil was used as the lubricant. Specimens were also upset at room temperature. Two samples were tested at each temperature.

\section{Results}

From the Force-Stroke diagrams generated, true stress against true strain was plotted at different temperatures (figure 1). True stress was plotted against temperature at different strains (figure 2). Log-log plot of stress $(\sigma)$ vs strain $(\varepsilon)$ is shown in figure 3 . Strength coefficient $(K)$ and strain hardening exponent ( $n$ ) (see Appendix) were plotted against temperature (figures 4 and 5). Adiabatic heating in the deformation zone was calculated (see Appendix) as shown in table 1, for a strain of 0.4 at different flow stresses, corresponding to temperatures of $303,373,473,573$ and $673 \mathrm{~K}$. 


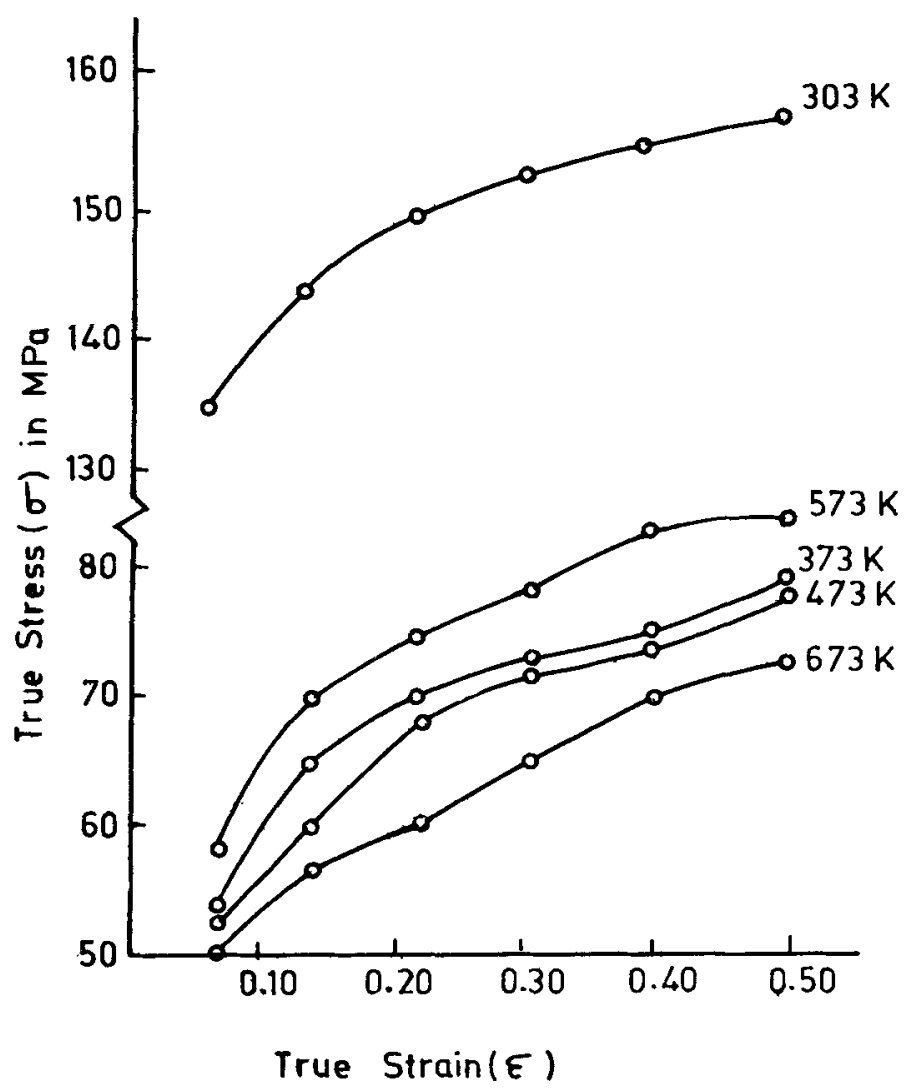

Figure 1. Plot of true stress against true strain at different temperatures.

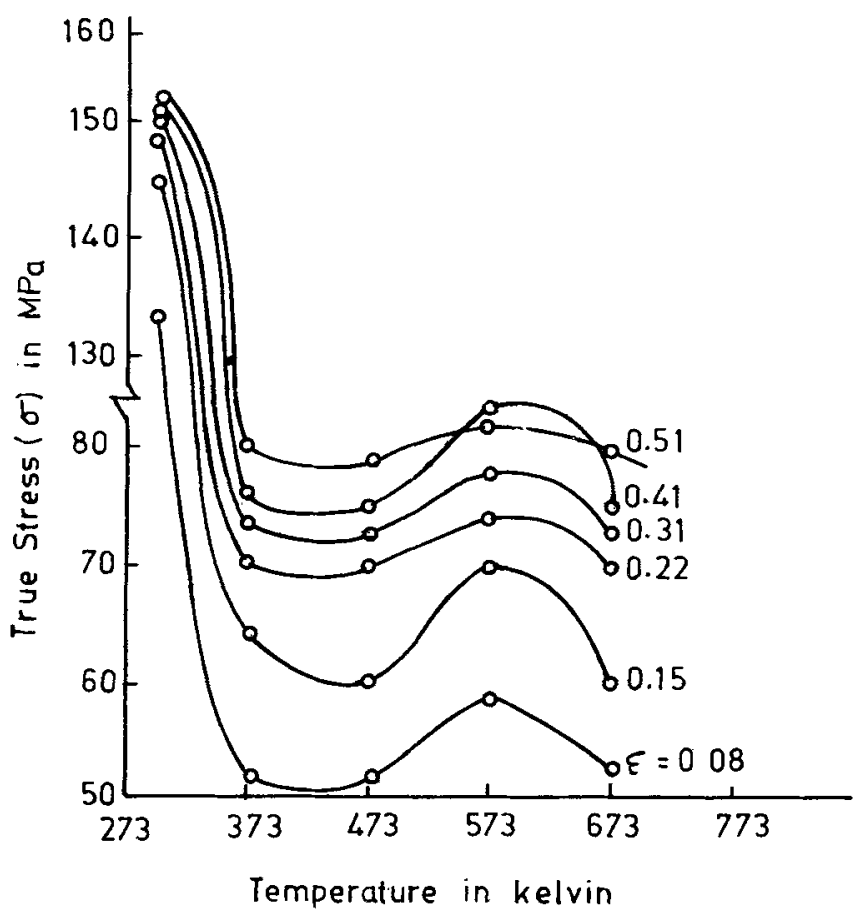

Figure 2. Plot of true stress against temperature at different strains.

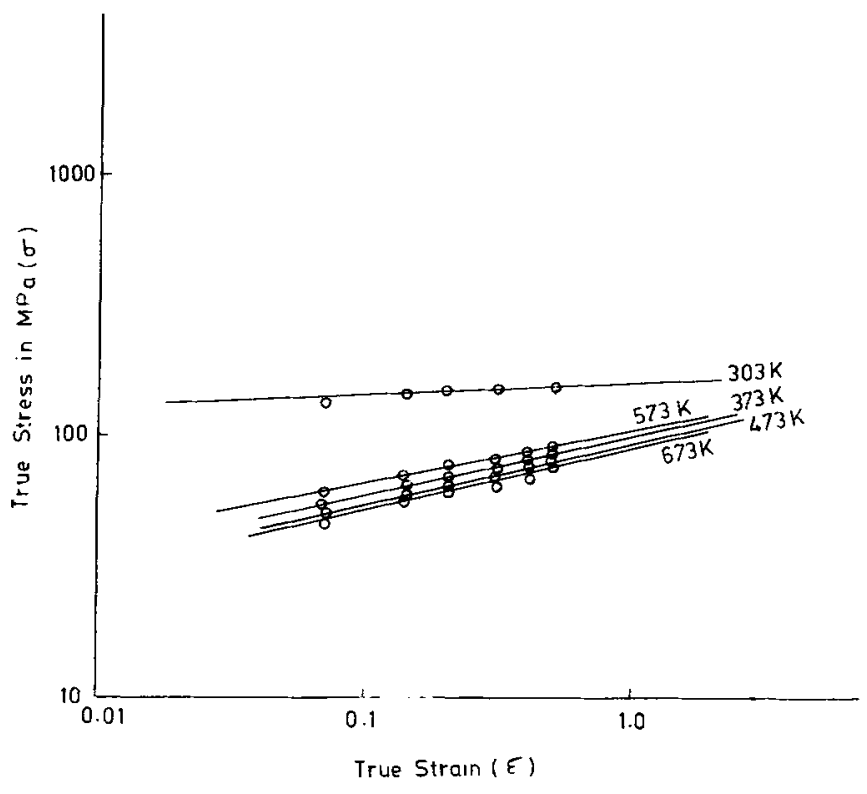

Figure 3. Log-log plot of true stress and true strain at different temperatures.

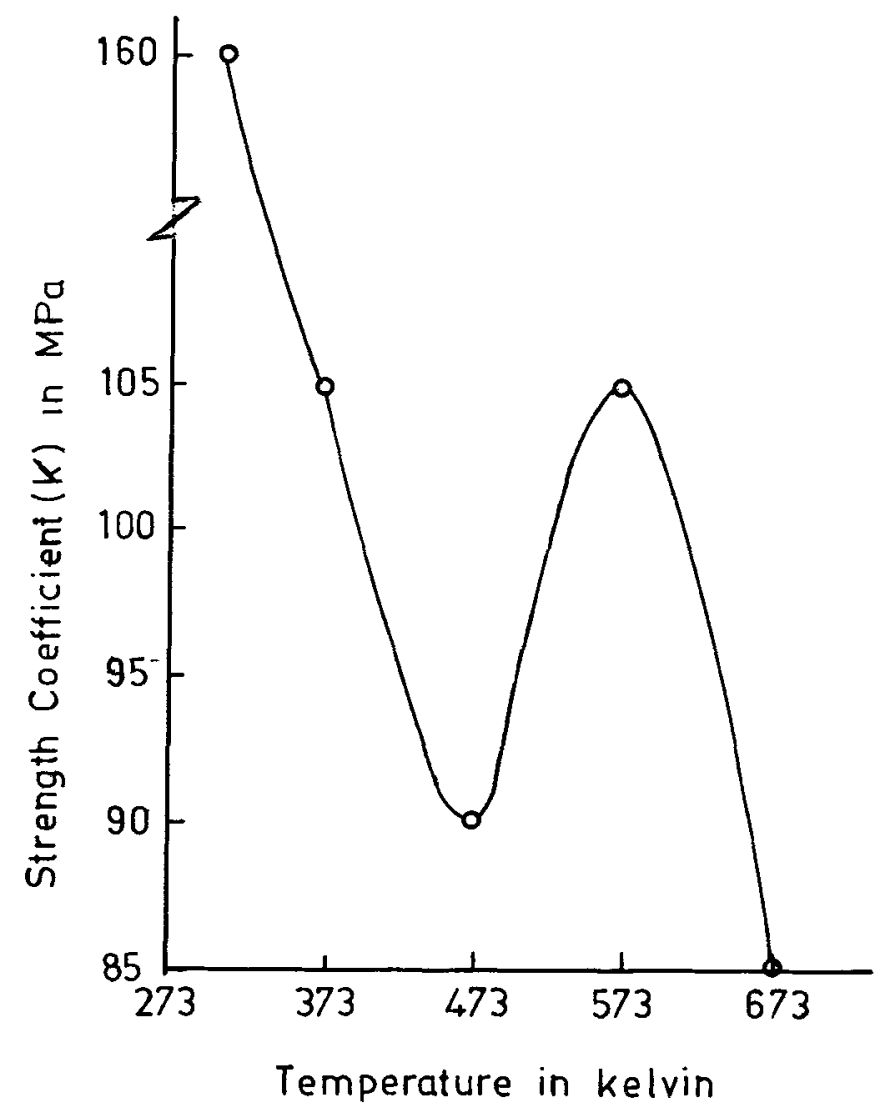

Figure 4. Plot of strength coefficient against temperature. 


\section{Discussion}

From figure 1 it is found that to impart higher strains higher stresses are required at a given temperature and higher the temperature (for a given strain) lower is the stress. From figure 2 it is found that between 473 and $673 \mathrm{~K}$ there is a peak in stress at all the strains from 0.08 to 0.41 . This peak shifts to higher temperatures at high strains. This is due to dynamic strain ageing. It is clearly brought out in figure 1 that stress vs strain curve for $573 \mathrm{~K}$ lies above that of $373 \mathrm{~K}, 473 \mathrm{~K}$ and $673 \mathrm{~K}$. $\log \sigma$ vs $\log \varepsilon$ is linear at all temperatures as seen from figure 3. $K$ and $n$ calculated from figure 3 shows peaks and valleys as seen in figures 4 and 5 .

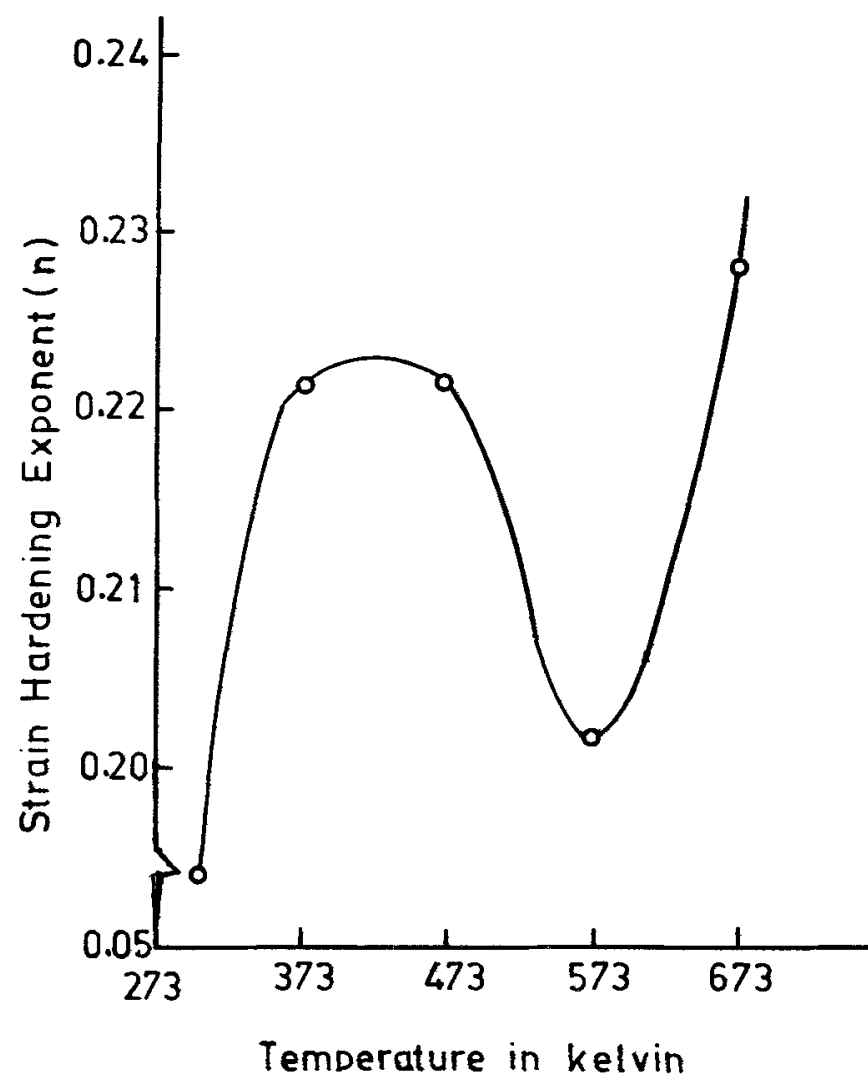

Figure 5. Plot of strain hardening exponent against temperature.

Table 1. Temperature rise due to adiabatic heating in aluminium.

\begin{tabular}{lccc}
\hline $\begin{array}{l}\text { Resident } \\
\text { temperature } \\
(\mathbf{K})\end{array}$ & $\begin{array}{c}\text { True stress } \\
(\sigma \text { in } \mathrm{MPa})\end{array}$ & $\Delta T_{\mathrm{ad}}$ & $\begin{array}{c}T_{\mathrm{w}}=T_{\mathrm{R}}+\Delta T_{\mathrm{ad}} \\
(\mathbf{K})\end{array}$ \\
\hline 303 & 151 & 24 & 327 \\
373 & 75 & 12 & 385 \\
473 & 70 & 11 & 484 \\
573 & 85 & 13 & 586 \\
673 & 70 & 11 & 684 \\
\hline
\end{tabular}

$K$ decreases with increase in temperature up to 473 $\mathrm{K}$, then increases up to $573 \mathrm{~K}$ and again comes down. It is the opposite for $n$. It increases and reaches a maximum at $423 \mathrm{~K}$, decreases up to $573 \mathrm{~K}$ and again reaches a maximum at $673 \mathrm{~K}$. It is due to DSA. Warm working temperature should be between 423 and $473 \mathrm{~K}$. For CP aluminium deformation at lower temperatures gives rise to a substructure of cells (Polmear 1995). These cells differ in orientation by only about $1^{\circ}$. The cell walls consist of tangled dislocations. Deformation at higher temperatures produces a substructure of subgrains (Polmear 1995) bounded by narrow well defined walls with a large orientation difference. Strengthening due to subgrains is more compared to that due to cells (Polmear 1995). The strengthening is given by

$$
\sigma_{\mathrm{y}}=\sigma_{0}+k\left(d_{\mathrm{g}}\right)^{-m}
$$

' $m$ ' changes from 1 to 0.5 as substructure changes from cells to subgrains. Therefore, $\sigma_{y}$ will be more for subgrains than for cells. But if the temperature is in the hotworking range the hardening effect due to strain is totally lost. To get subgrains and avoid cells one must work CP aluminium at higher temperatures. From this aspect it is found that warm working will be attractive. One can get partial strain hardening and full substructure strengthening in warm working. By avoiding temperatures above $473 \mathrm{~K}$ one can sidestep the dangers of DSA, namely higher stresses and easier cracking.

\section{Conclusion}

To get maximum strength after mechanical processing in commercial purity aluminium, warm working between 423 and $473 \mathrm{~K}$ is very attractive. Lower temperatures give rise to higher forces due to higher stresses. Higher temperatures also give rise to higher forces and stresses because of DSA. Warm working near $473 \mathrm{~K}$ alone will give additional strengthening, by developing a substructure of subgrains.

\section{Appendix}

I. Holloman's flow curve equation:

$$
\sigma=K \varepsilon^{n} \text {. }
$$

II. Estimation of ' $\boldsymbol{K}$ ':

$\ln \sigma=\ln K+n \ln \varepsilon$,

$\varepsilon=1, \ln \sigma=\ln K$,

$\sigma_{(z=1)}=K$. 
III. Estimation of ' $n$ ':

$$
\begin{aligned}
& \ln \sigma_{1}=\ln K+n \ln \varepsilon_{1}, \\
& \ln \sigma_{2}=\ln K+n \ln \varepsilon_{2} \\
& \left(\ln \sigma_{2}-\ln \sigma_{1}\right) /\left(\ln \varepsilon_{2}-\ln \varepsilon_{1}\right)=n .
\end{aligned}
$$

IV. Determination of adiabatic heating:

$$
\begin{aligned}
& \Delta T_{\mathrm{ad}}=(\beta \sigma \varepsilon) /(\rho c) \text { where } \beta=0.95, \varepsilon=0.4, \\
& \rho=2.69 \times 10^{3} \mathrm{~kg} / \mathrm{m}^{3}, \\
& c=900 \mathrm{~J} / \mathrm{kg} \mathrm{K}, \\
& (1 / \rho c)=0.41 \times 10^{-6} \mathrm{~m}^{2} \mathrm{~K} / \mathrm{N} \\
& \Delta T_{\mathrm{ad}}=\left[(0.16)(\sigma) \times 10^{-6}\right] \text { where } \sigma \text { is in } \mathrm{MPa} .
\end{aligned}
$$

\section{List of symbols}

$\sigma$, true stress;

$\sigma_{\mathrm{i}}$, initial stress

$\sigma_{y}$, yield stress;

$\sigma_{0}$, Peierls stress;

$\sigma_{\mathrm{f}}$, final stress;

$\beta$, constant $=0.95$;

$c$, specific heat of workpiece;

$d_{0}$, diameter of billet (initial);

$d_{\mathrm{g}}$, diameter of subgrain or cell;

$\varepsilon$, true strain;

$\varepsilon_{i}$, initial strain;

$\varepsilon_{\mathrm{f}}$, final strain

$\varepsilon_{\mathrm{y}}$, strain at yield;

$h_{0}$, height of billet (initial);

$K$, strength coefficient;

$\mathrm{K}$, degree kelvin; $k$, constant;

(1) $m$, exponent;

(2) $n$, strain hardening exponent;

$\rho$, density;

$T_{w}$, working temperature;

$T_{\mathrm{m}}$, melting point $=933 \mathrm{~K}$ for $\mathrm{CP}$ aluminium;

$R T$, room temperature;

$\Delta T_{\mathrm{ad}}$, temperature rise due to adiabatic heating;

$T_{\mathrm{R}}$, resident temperature.

\section{References}

Avner S H 1974 Introduction to physical metallurgy (Auckland: McGraw Hill) p. 141

Begstrom Y and Aronsson B 1971 Metall. Trans. 31951

Dieter G E and Bacan D 1988 Mechanical metallurgy (London: McGraw Hill) p. 535

Hammand A M 1987 Trans. IIM Calcutta 40423

Hammand A M, Padmanabhan K A and Anantharaman T R 1977 Trans. IIM Calcutta 30327

Hammand A M, Padmanabhan K A and Anantharaman T R 1980 J. Mater. Sci. 152136

Hatch J E 1984 Aluminium properties and physical metallurgy (Ohio: ASM) p. 105

Lange K 1985 Handbook of metal forming (New York: McGraw Hill) p. 111

Polmear I J 1995 Light alloys metallurgy of the light metals (London: Arnold Publishers) p. 100

Rao K P and Prasad Y V R K 1986 Trans. IIM Calcutta 39 313

Rao K P, Roshan H Md, Doraivelu S M and Prasad Y V R K 1984a Trans. IIM Calcutta 37465

Rao K P, Doraivelu S M, Roshan H Md and Prasad Y V R K 1984b Trans. IIM Calcutta 37471

Reed Hill R E and Reza Abbaschian 1994 Physical metallurgy principles (Boston: PWS) p. 904

Van Horn K R 1967 Aluminum-Fabrication and finishing (Ohio: ASM) Vol. III p. 82 